\title{
Abnormal uterine bleeding: a clinicohistopathological analysis
}

\author{
Anupamasuresh $\mathbf{Y}^{1 *}$, Suresh $\mathbf{Y V}^{2}$, Prachi Jain ${ }^{1}$
}

\author{
${ }^{1}$ Department of Obstetrics \& Gynecology, Kasturba Medical College, Mangalore, Karnataka, India \\ ${ }^{2}$ Department of Anesthesiology, Kasturba Medical College, Mangalore, Karnataka, India
}

Received: 15 July 2014

Accepted: 8 August 2014

\author{
*Correspondence: \\ Dr. Anupamasuresh Y, \\ E-mail: dranupamasureshy@yahoo.co.in
}

(C) 2014 Anupamasuresh Y et al. This is an open-access article distributed under the terms of the Creative Commons Attribution Non-Commercial License, which permits unrestricted non-commercial use, distribution, and reproduction in any medium, provided the original work is properly cited.

\begin{abstract}
Background: Abnormal uterine bleeding (AUB) is one of the most common problem for the patients and the gynecologists. It adversely effects on the quality of life and psychology of women. It is of special concern in developing country as it adds to the causes of anemia. Management of Abnormal Uterine Bleeding (AUB) is not complete without tissue diagnosis especially in perimenopausal and post-menopausal women. Histological characteristics of endometrial biopsy material as assessed by light microscopy remains the diagnostic standard for the diagnosis of endometrial pathology.

Methods: In our prospective study of 359 Patients of the age between $46 \& 73$ years, clinical characteristics and the pattern of endometrial histopathology and their association in women, who present with abnormal uterine bleeding, are categorised into six groups.

Results: In our study, a significant correlation of histopathology \& BMI was observed with endometrial hyperplasia and malignancy in obese patient i.e. 37 out 96 and 13 out of 23 respectively. The incidence of malignancy has been increasing with the age being $1.6 \%$ in $46-50$ years to $60 \%$ in $70-75$ years. In our study $116(32.3 \%)$ had hypertension, 33 patients $(9.2 \%)$ had diabetes mellitus, 40 patients $(11.1 \%)$ had hypothyroidism.

Conclusions: We found a maximum incidence of AUB in multiparous women. Clinicohistopathological analysis of AUB revealed endometrial hyperplasia in majority of patients.
\end{abstract}

Keywords: Abnormal uterine bleeding (AUB), Endometrial hyperplasia, malignancy, Hypertension, Diabetes mellitus

\section{INTRODUCTION}

Abnormal Uterine Bleeding (AUB) is considered as one of the most common and perplexing problem both for the patients and the gynecologists. It has an adverse effect on the quality of life and psychological state of women. It is of special concern in developing country as it adds to the causes of anemia which is already prevailing in women. Management of Abnormal Uterine Bleeding (AUB) is not complete without tissue diagnosis especially in perimenopausal and post-menopausal women. Accurate analysis of endometrial sampling ${ }^{1}$ and localization of intrauterine lesions is the goal to effective management and better outcome of problem. Histological characteristics of endometrial biopsy material as assessed by light microscopy remains the diagnostic standard for the diagnosis of endometrial pathology.

\section{METHODS}

This was a prospective observational study. A total of 359 women, who are more than 45 years of age with abnormal uterine bleeding, who needed endometrial curettage were included in the study. Written, informed consent was taken from the patients. We recorded the details in the designed proforma which included the information about, patient characteristics, obstetric profile, pattern of bleeding, history of drug intake and 
medical history. The type of abnormal uterine bleeding and the pattern of blood loss were described according to the FIGO recommendations on terminologies and definitions for normal and abnormal uterine bleeding. Amount of bleeding was assessed using pictorial blood assessment chart. General physical examination and local examination was performed. Patients on admission, were screened for hypertension, diabetes mellitus and hypothyroidism. Endometrial curettage was performed by a gynecologist and specimens were transported in $10 \%$ formalin to the pathology laboratory. Microscopic examination was done by pathologists. We recorded the details in the designed proforma that included information about patient characteristics, obstetric profile, pattern of bleeding and co morbidities.

Inclusion criteria: we included women with isolated endometrial causes of abnormal uterine bleeding, more than 45 years of age, undergoing endometrial curettage, in the study.

Exclusion criteria: we excluded women with coagulation disorders (thrombocytopathies, Von Willebrand's disease, and leukemia) and on medications including antiplatelets and anticoagulants, Findings were tabled.

\section{RESULTS}

Total 369 patients were included in the study from the age group of 45 years to 73 years.

Table 1: Age distribution of the patients with AUB.

\begin{tabular}{|lll|}
\hline Age group & Frequency & Percentage \\
\hline $46-50$ & 188 & 52.4 \\
\hline $51-55$ & 102 & 28.4 \\
\hline $56-60$ & 33 & 9.2 \\
\hline $61-65$ & 23 & 6.4 \\
\hline $66-70$ & 8 & 2.2 \\
\hline $71-75$ & 5 & 1.4 \\
\hline Total & 359 & 100 \\
\hline
\end{tabular}

Table 4: Histopathological distribution in different age groups of the patients with AUB.

\begin{tabular}{|lllllll|l|}
\hline Histopathology & $46-50$ & $51-55$ & $56-60$ & $61-65$ & $66-70$ & $71-75$ & Total \\
\hline Normal cyclical pattern & $50(26.6 \%)$ & $34(33.3 \%)$ & $6(18.2)$ & $3(13.9 \%)$ & $1(12.5 \%)$ & $0(0 \%)$ & $94(26.2 \%)$ \\
\hline Atrophic endometrium & $5(2.7 \%)$ & $4(3.9 \%)$ & $3(9.1 \%)$ & $3(13 \%)$ & $3(37.5 \%)$ & $2(40 \%)$ & $20(5.6 \%)$ \\
\hline Endometrial polyp & $16(8.5 \%)$ & $10(9.8 \%)$ & $2(6.1 \%)$ & $2(8.7 \%)$ & $1(12.5 \%)$ & $0(0 \%)$ & $31(8.6 \%)$ \\
\hline $\begin{array}{l}\text { Disordered proliferative } \\
\text { endometrium }\end{array}$ & $18(9.6 \%)$ & $13(12.7 \%)$ & $4(12.1 \%)$ & $2(8.7 \%)$ & $0(0 \%)$ & $0(0 \%)$ & $37(10.3 \%)$ \\
\hline Endometrial hyperplasia & $59(31.4 \%)$ & $24(23.5 \%)$ & $9(27.3 \%)$ & $4(17.4 \%)$ & $0(0 \%)$ & $0(0 \%)$ & $96(26.7 \%)$ \\
\hline Endometrial malignancy & $3(1.6 \%)$ & $4(3.9 \%)$ & $6(18.2 \%)$ & $5(21.7 \%)$ & $2(25 \%)$ & $3(60 \%)$ & $23(6.4 \%)$ \\
\hline Others & $37(19.7 \%)$ & $13(12.7 \%)$ & $3(9.1 \%)$ & $4(17.4 \%)$ & $1(12.5 \%)$ & $0(0 \%)$ & $58(16.2 \%)$ \\
\hline Total & $188(100 \%)$ & $102(100 \%)$ & $33(100 \%)$ & $23(100 \%)$ & $8(100 \%)$ & $5(100 \%)$ & $359(100 \%)$ \\
\hline
\end{tabular}

$* \mathrm{P}$ value $<0.01$; Chi-square test

There are 188 patients were in the age group of 46 to 50 years $(52.4 \%)$.

Table 2: Parity distribution of the patients with AUB.

\begin{tabular}{|lll|}
\hline Parity & Frequency & Percentage \\
\hline Nulliparous & 23 & 6.4 \\
\hline Primiparous & 135 & 37.6 \\
\hline Multiparous & 192 & 53.5 \\
\hline Grandmultiparous & 9 & 2.5 \\
\hline Total & 359 & 100 \\
\hline
\end{tabular}

Majority of our patients were multiparous women (192 patients, $53.5 \%$ ). 135 patients, $37.5 \%$ were primiparous; 23 patients, $6.4 \%$ were nulliparous; 9 patients, $2.5 \%$ were grandmultiparous.

No significant association was found between pattern of histopathology \& parity distribution with a $\mathrm{P}$ value of 0.67 .

\section{Type of $A U B$}

Table 3 shows Type of AUB.

Table 3: Type of AUB.

\begin{tabular}{|lll|}
\hline Type of AUB & Frequency & Percentage \\
\hline Acute AUB & 61 & 16.9 \\
\hline Chronic AUB & 87 & 24.2 \\
\hline Acute on chronic AUB & 44 & 12.2 \\
\hline Intermenstrual bleeding & 11 & 3.1 \\
\hline Post-menopausal bleeding & 157 & 43.6 \\
\hline Total & 359 & 100 \\
\hline
\end{tabular}

A significant association was found between pattern of histopathology \& type of AUB with a $\mathrm{P}$ value of $<0.01$. As seen in the above table 157 (43.6\%) patients presented with post-menopausal bleeding, followed by 87 (24.2\%) patients with chronic AUB. 
Most commonly found histopathology was endometrial hyperplasia (26.7\%). The incidence of malignancy has been increasing with the age being $1.6 \%$ in $46-50$ years to $60 \%$ in $70-75$ years.

Table 5: Histopathological distribution in different studies of the patients with AUB.

\begin{tabular}{|c|c|c|c|c|c|}
\hline Histopathology & $\begin{array}{l}\text { Doraiswami et al. } \\
\text { ( } 409 \text { patients) }\end{array}$ & $\begin{array}{l}\text { Baral et al. } \\
\text { (300 patients) }\end{array}$ & $\begin{array}{l}\text { Smitha et al. } \\
\text { (210 patients) }\end{array}$ & $\begin{array}{l}\text { Sarvat et al. } \\
\text { (161 patients) }\end{array}$ & $\begin{array}{l}\text { Present study } \\
\text { (359 patients) }\end{array}$ \\
\hline Normal cyclical pattern & $28.3 \%$ & $36.6 \%$ & $24.28 \%$ & $34.1 \%$ & $26.2 \%$ \\
\hline Atrophic endometrium & $2.4 \%$ & - & - & - & $5.6 \%$ \\
\hline Endometrial polyp & $11.2 \%$ & - & $5.7 \%$ & $4.3 \%$ & $8.9 \%$ \\
\hline $\begin{array}{l}\text { Disordered proliferative } \\
\text { endometrium }\end{array}$ & $20.5 \%$ & $26.6 \%$ & - & - & $10.3 \%$ \\
\hline Chronic endometritis & $4.1 \%$ & $2.6 \%$ & $7.1 \%$ & $6.2 \%$ & $6.4 \%$ \\
\hline Inadequate sample & - & $8.3 \%$ & - & - & $9.5 \%$ \\
\hline Hyperplasia & $6.1 \%$ & $18.3 \%$ & $41.9 \%$ & $27.9 \%$ & $26.7 \%$ \\
\hline Endometrial malignancy & $4.4 \%$ & $1 \%$ & $2.38 \%$ & $1.86 \%$ & $6.4 \%$ \\
\hline
\end{tabular}

The present study included only perimenopausal and post-menopausal women which lead to a greater number of women with malignancy $(6.4 \%)$ as compared to other studies which included all the women from menarche to menopause (Table 5). A significant association was found between pattern of histopathology \& BMI with a $\mathrm{P}$ value of $<0.01$. Majority of the patients with endometrial hyperplasia and malignancy were obese 37 out 96 and 13 out of 23 respectively. In the group of participants with underweight and normal BMI normal cyclical pattern was most commonly found in 32 out of 50 and 28 out of 95 patients respectively. In pre obese and obese group endometrial hyperplasia was most prevalent in 34 of 97 and 37 of 117 patients respectively (Table 6).

Table 6: BMI distribution with pattern of histopathology of the patients with AUB.

\begin{tabular}{|llllll|}
\hline Histopathology & Under weight & Normal & Pre-obese & Obese & Total \\
\hline Normal cyclical pattern & $\mathbf{1 8 . 5 0}$ & $\mathbf{1 8 . 5 0 - 2 4 . 9 9}$ & $\mathbf{2 5 . 0 0 - 2 9 . 9 9}$ & $\mathbf{3 0 . 0 0}$ & (25) \\
\hline Atrophic endometrium & $32(8.9 \%)$ & $28(7.8 \%)$ & $16(4.5 \%)$ & $18(5 \%)$ & $94(26.2 \%)$ \\
\hline Endometrial polyp & $1(0.3 \%)$ & $4(1.1 \%)$ & $5(1.4 \%)$ & $10(2.9 \%)$ & $20(5.6 \%)$ \\
\hline Disordered proliferative endometrium & $4(1.1 \%)$ & $10(2.8 \%)$ & $10(2.8 \%)$ & $7(1.9 \%)$ & $31(8.6 \%)$ \\
\hline Endometrial hyperplasia & $9(2.5 \%)$ & $12(3.3 \%)$ & $12(2.2 \%)$ & $8(2.2 \%)$ & $37(10.3 \%)$ \\
\hline Endometrial malignancy & $1(0.3 \%)$ & $24(6.7 \%)$ & $34(9.5 \%)$ & $37(10.3 \%)$ & $96(26.7 \%)$ \\
\hline Others & $2(0.6 \%)$ & $3(0.8 \%)$ & $5(1.4 \%)$ & $13(3.6 \%)$ & $23(6.4 \%)$ \\
\hline Total & $1(0.3 \%)$ & $14(3.9 \%)$ & $19(5.3 \%)$ & $24(6.7 \%)$ & $58(16.2 \%)$ \\
\hline
\end{tabular}

$* \mathrm{P}$ value $<0.01 ;$ Chi-square test

Table 7: Hypertension with pattern of histopathology of the patients with AUB.

\begin{tabular}{|llll|}
\hline Histopathology & Hypertensives & Normotensives & Total \\
\hline Normal cyclical pattern & $8(2.2 \%)$ & $86(24 \%)$ & $94(26.2 \%)$ \\
\hline Atrophic endometrium & $12(3.3 \%)$ & $8(2.2 \%)$ & $20(5.6 \%)$ \\
\hline Endometrial polyp & $5(1.4 \%)$ & $26(7.2 \%)$ & $31(8.6 \%)$ \\
\hline Disordered proliferative endometrium & $1(0.3 \%)$ & $36(10 \%)$ & $37(10.3 \%)$ \\
\hline Endometrial hyperplasia & $68(18.9 \%)$ & $28(7.8 \%)$ & $96(26.7 \%)$ \\
\hline Endometrial malignancy & $14(3.9 \%)$ & $9(2.5 \%)$ & $23(6.4 \%)$ \\
\hline Others & $8(2.2 \%)$ & $50(13.9 \%)$ & $58(16.2 \%)$ \\
\hline Total & $116(32.3 \%)$ & $243(67.7 \%)$ & $359(100 \%)$ \\
\hline
\end{tabular}

$* \mathrm{P}$ value $<0.01 ;$ Chi-square test 
A significant association was found between pattern of histopathology \& hypertension with a p value of $<0.01$. Hypertension was more common in patients with atrophic endometrium, endometrial hyperplasia and endometrial malignancy with 12 out of 20,68 out of 96 and 14 out of 23 patients respectively. Majority of the patients 68 out of 116 with hypertension had endometrial hyperplasia.

Table 8: Diabetes with pattern of histopathology of the patients with AUB.

\begin{tabular}{|llll|}
\hline $\begin{array}{l}\text { Histopathology } \\
\text { pormal cyclical }\end{array}$ & $3(0.8 \%)$ & $91(25.3 \%)$ & $94(26.2 \%)$ \\
\hline $\begin{array}{l}\text { Atrophic } \\
\text { endometrium }\end{array}$ & $6(1.7 \%)$ & $14(3.9 \%)$ & $20(5.6 \%)$ \\
\hline $\begin{array}{l}\text { Endometrial } \\
\text { polyp }\end{array}$ & $1(0.3 \%)$ & $30(8.4 \%)$ & $31(8.6 \%)$ \\
\hline $\begin{array}{l}\text { Disordered } \\
\text { proliferative } \\
\text { endometrium }\end{array}$ & $0(0 \%)$ & $37(10.3 \%)$ & $37(10.3 \%)$ \\
\hline $\begin{array}{l}\text { Endometrial } \\
\text { hyperplasia }\end{array}$ & $16(4.5 \%)$ & $80(22.3 \%)$ & $96(26.7 \%)$ \\
\hline $\begin{array}{l}\text { Endometrial } \\
\text { malignancy }\end{array}$ & $6(1.7 \%)$ & $17(4.7 \%)$ & $23(6.4 \%)$ \\
\hline Others & $1(0.3 \%)$ & $57(15.9 \%)$ & $58(16.2 \%)$ \\
\hline Total & $33(9.2 \%)$ & $326(90.8 \%)$ & $359(100 \%)$ \\
\hline
\end{tabular}

$* \mathrm{P}$ value $<0.01 ;$ Chi-square test

A significant association was found between pattern of histopathology \& diabetes with a $\mathrm{p}$ value of $<0.01$. Diabetes was more common in patients with atrophic endometrium, endometrial hyperplasia and endometrial malignancy with 6 out of 20, 16 out of 96 and 6 out of 23 patients respectively. Majority of the patients 16 out of 33 with diabetes had endometrial hyperplasia.

Table 9: Hypothyroidism with pattern of histopathology of the patients with AUB.

\begin{tabular}{|llll|}
\hline Histopathology & $\begin{array}{l}\text { Hypo- } \\
\text { thyroids }\end{array}$ & $\begin{array}{l}\text { Non hypo- } \\
\text { thyroids }\end{array}$ & Total \\
\hline $\begin{array}{l}\text { Normal cyclical } \\
\text { pattern }\end{array}$ & $6(1.7 \%)$ & $88(24.5 \%)$ & $94(26.2 \%)$ \\
\hline $\begin{array}{l}\text { Atrophic } \\
\text { endometrium }\end{array}$ & $1(0.3 \%)$ & $19(5.3 \%)$ & $20(5.6 \%)$ \\
\hline $\begin{array}{l}\text { Endometrial } \\
\text { polyp }\end{array}$ & $4(1.1 \%)$ & $27(7.5 \%)$ & $31(8.6 \%)$ \\
\hline $\begin{array}{l}\text { Disordered } \\
\text { proliferative } \\
\text { endometrium }\end{array}$ & $4(1.1) \%$ & $33(9.2 \%)$ & $37(10.3 \%)$ \\
\hline $\begin{array}{l}\text { Endometrial } \\
\text { hyperplasia }\end{array}$ & $19(5.3) \%$ & $77(21.4 \%)$ & $96(26.7 \%)$ \\
\hline $\begin{array}{l}\text { Endometrial } \\
\text { malignancy }\end{array}$ & $6(1.7) \%$ & $17(4.7 \%)$ & $23(6.4 \%)$ \\
\hline Others & $0(0 \%)$ & $58(16.2 \%)$ & $58(16.2 \%)$ \\
\hline Total & $40(11.1 \%)$ & $319(88.9 \%)$ & $359(100 \%)$ \\
\hline
\end{tabular}

$* \mathrm{P}$ value $<0.01$; Chi-square test
A significant association was found between pattern of histopathology \& hypothyroidism with a $\mathrm{P}$ value of $<0.01$. Hypothyroidism was more common in patients with endometrial hyperplasia and endometrial malignancy with 19 out of 96 and 6 out of 23 patients respectively. Majority of the patients 19 out of 40 with hypothyroidism had endometrial hyperplasia.

\section{Pattern of bleeding in perimenopausal women}

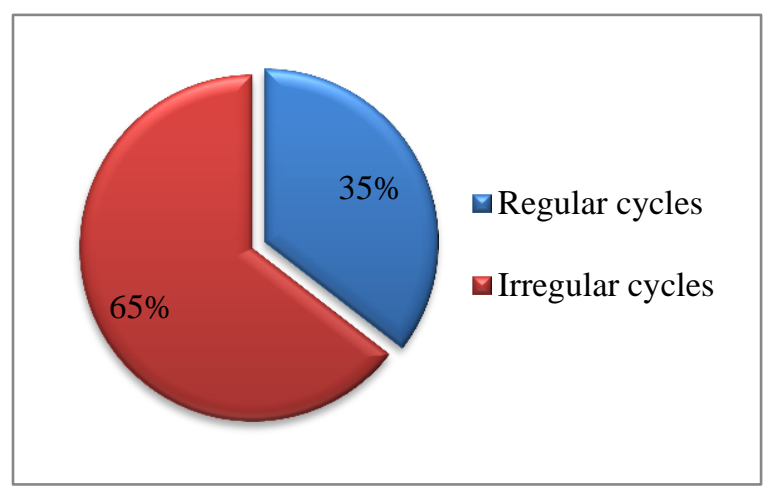

Figure 1: Regularity of menstrual cycle.

The most commonly noted pattern of bleeding was irregular cycles in $65 \%$ of women.

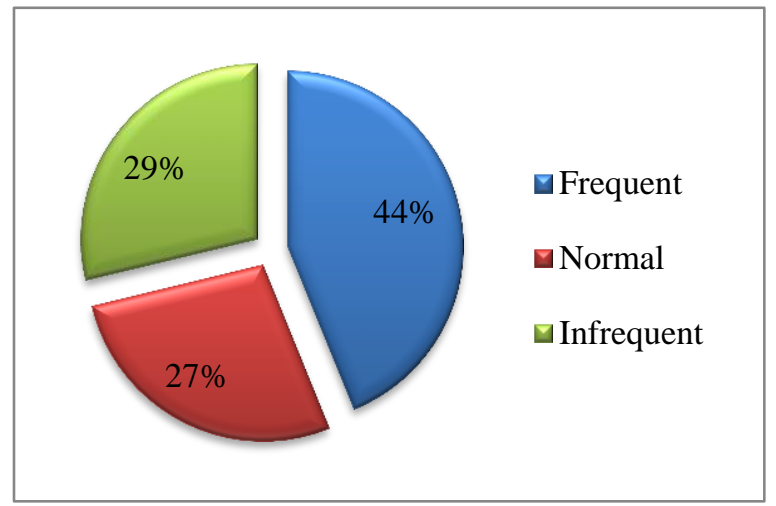

Figure 2: Frequency of menstrual cycle.

Increased frequency of cycles was found in majority of patients $(44 \%)$.

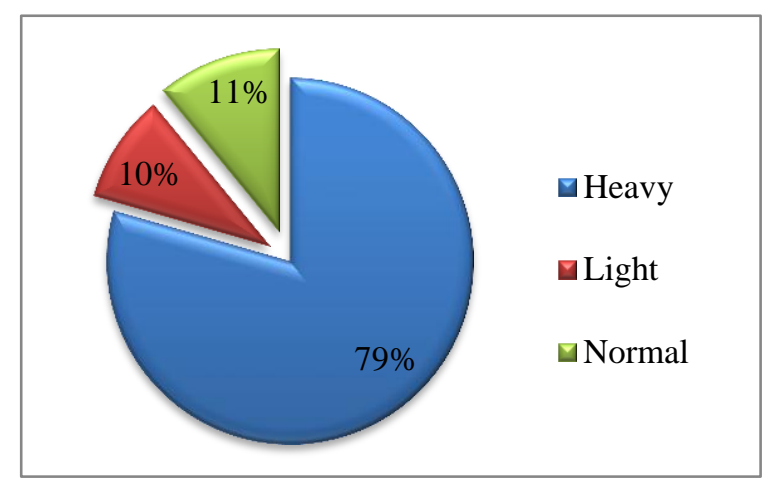

Figure 3: Amount of flow during menstrual cycle. 
Heavy bleeding $(80 \mathrm{ml}<)$ was found in $79 \%$ of our participants.

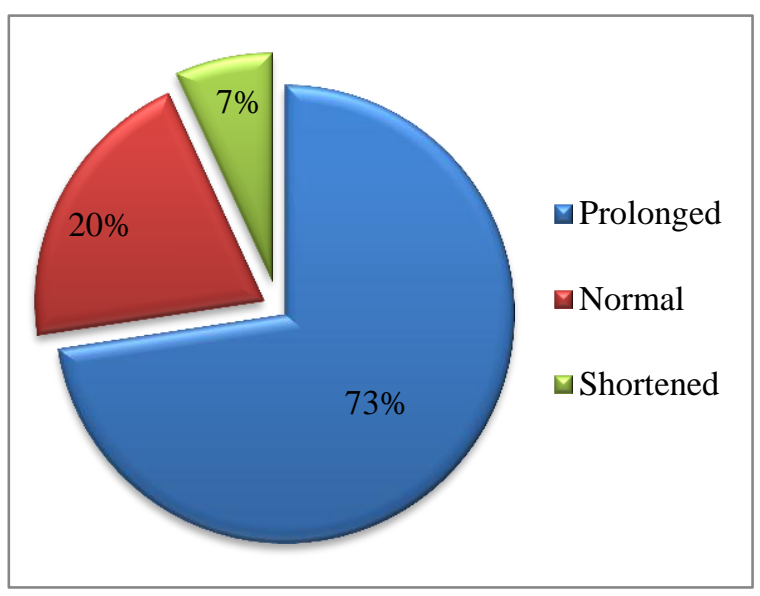

Figure 4: Duration of flow during menstrual cycle.

No significant association was found between pattern of histopathology \& bleeding pattern with a $\mathrm{P}$ value of $>0.05$. The most commonly noted pattern of bleeding was prolonged bleeding in $73 \%$ of the patients.

\section{DISCUSSION}

AUB is one of the most frequent complaints from the gynecological patients. Dilatation and curettage is the common procedure done to evaluate AUB. ${ }^{1}$

In our study 359 patients were included from 46 to 73 years of age. In our present study the age group which was most susceptible to abnormal uterine bleeding was 46-50 years with $52.4 \%$ of patients (Table 1 ).

Doraiswami et al. noted in 41-50 years age group with $33.5 \%$ patients. ${ }^{4}$ The reason for increased incidence of AUB in this age group may be due to the fact that these women are in their climacteric period approaching menopause, when cycles become intermittently anovulatory due to decline in the number of ovarian follicles and estradiol level.

We found a maximum incidence $(53.5 \%)$ of AUB in multiparous women (Table 2). A similar result was also found by Rajesh Patil et al. with a percentage of $71.58 \%$, Smitha et al. got $60.95 \%$. Most commonly found histopathology was endometrial hyperplasia $(26.7 \%){ }^{3}$ The incidence of malignancy has been increasing with the age being $1.6 \%$ in $46-50$ years to $60 \%$ in $70-75$ years.

Postmenopausal women accounted for $43.6 \%$ of our patients (Table 3). A significant association was found between pattern of histopathology \& type of AUB with a $\mathrm{P}$ value of $<0.01$. As seen in the table $157(43.6 \%)$ patients presented with post-menopausal bleeding, followed by $87(24.2 \%)$ patients with chronic AUB. Amongst the women in perimenopausal age group the most common type of abnormal uterine bleeding was chronic AUB. The most commonly noted pattern of bleeding was irregular cycles in $65 \%$ of women, increased frequency of cycles in $44 \%$, heavy bleeding in $79 \%$ and prolonged bleeding in $73 \%$. We found endometrial hyperplasia as the most common pathological lesion $(26.7 \%)$ on histopathology (Table 4).

Ara and Roohi noted hyperplasia in $27.95 \%$ of cases. ${ }^{5}$ Smitha et al. was $41.90 \%^{6}$ The incidence of hyperplasia was $6.1 \%$ in Doraiswami et al. (Table 5).

A significant association was found between pattern of histopathology \& BMI with a P value of $<0.01$. Majority of the patients with endometrial hyperplasia and malignancy were obese 37 out 96 and 13 out of 23 respectively. In the group of participants with underweight and normal BMI normal cyclical pattern was most commonly found in 32 out of 50 and 28 out of 95 patients respectively. In pre obese and obese group endometrial hyperplasia was most prevalent in 34 of 97 and 37 of 117 patients respectively (Table 6). ${ }^{7}$ Another significant relation was found between pattern of histopathology \& hypertension and diabetes ${ }^{7}$ with a $\mathrm{P}$ value of $<0.01$. Hypertension was more common in patients with atrophic endometrium, endometrial hyperplasia and endometrial malignancy with 12 out of 20,68 out of 96 and 14 out of 23 patients respectively. Majority of the patients 68 out of 116 with hypertension had endometrial hyperplasia (Table 7).

Also there with diabetes mellitus as majority of these patients 16 out of 33 with diabetes had endometrial hyperplasia (Table 8).

We have also observed that in hypothyroidism patients a significant $P$ value of $<0.01$. With endometrial hyperplasia and endometrial malignancy with 19 out of 96 and 6 out of 23 patients respectively (Table 9).

Funding: No funding sources

Conflict of interest: None declared

Ethical approval: The study was approved by the institutional ethics committee

\section{REFERENCES}

1. Samson, S-L, Donna G. Who needs an endometrial biopsy? Can Fam Physician. 2002;48:885.

2. Patil R, Patil RK, Andola SK, Laheru V, Bhandar M. Histopathological spectrum of endometrium in dysfunctional uterine bleeding. Int $\mathrm{J}$ Bio Med Res. 2013;4(1):2798-801.

3. Sarwat A, Roohi M. Histological diagnosis by conventional dilatation and curettage. Professional Med J. 2011;18(4):587-91.

4. Saraswathi D, Thanka J. Study of endometrial pathology in abnormal uterine bleeding. J Obstet Gynecol India. 2011;61(4):426-30. 
5. Sarwat A, Roohi M. Histological diagnosis by conventional dilatation and curettage. Professional Med J. 2011;18(4):587-91.

6. Smita S. Patne, Manik S. Sirpurkar. Validation of endometrial curettage in abnormal uterine bleeding in a teaching institute of central India: a prospective study. Int J Med Res Health Sci. 2013;2(3):491-5.
7. Padubidri VG, Daftary SN. Gynecologic oncology. In: Padubidri VG, Daftary SN, eds. Shaw's Textbook of Gynecology. 15th ed. India: Elsevier; 2010: 471.

DOI: 10.5455/2320-1770.ijrcog20140954

Cite this article as: Anupamasuresh Y, Suresh YV, Jain P. Abnormal uterine bleeding: a clinicohistopathological analysis. Int J Reprod Contracept Obstet Gynecol 2014;3:656-61. 